\title{
Synthesis and thermal properties of some phenolic resins
}

\section{Síntesis y propiedades térmicas de algunas resinas fenólicas}

Author:

Alshawi F M ${ }^{1}$

Abdul Razzq $\mathbf{K}^{2}$

Hanoosh W S ${ }^{3}$

\section{SCIENTIFIC RESEARCH}

How to cite this paper:

Alshawi F M, Abdul Razzq K., Hanoosh W S., Synthesis and thermal properties of some phenolic resins. Innovaciencia. 2019; 7 (1):1-16. http://dx.doi.org/10.15649/2346075X.508

Reception date:

Received: 11 February 2019

Accepted: 24 April 2019

Published: 25 October 2019

Keywords:

Phenolic resin, Physical properties, TGA, DSC

\section{ABSTRACT}

Introduction: Phenolic resins have been in use since the early twentieth century and are considered the first class of synthetic polymers to achieve commercial success, moreover phenolic resins continue to succeed and attract special interest in a large range of industrial applications such as adhesives, paints, and composites; because of their unique physical and chemical properties. Materials and Methods: Prepolymers resol resins (RR, RH, RP, and RC) were synthesized by the reaction of phenolic compounds (resorcinol, hydroquinone, phloroglucinol, and catechol) respectively, with formaldehyde at molar ratio phenol/ formaldehyde $1 / 1.5$, using sodium hydroxide as a catalyst. These resins were characterized by FTIR. The curing reaction of these resins was evaluated using differential scanning calorimetry (DSC), while the thermal stability study was evaluated using thermogravimetric analysis (TGA). Results and Discussion: From the results showing that these prepolymers have different curing temperatures and curing energy, while the TGA study showed that the cured resins have decomposition temperature more than $300^{\circ} \mathrm{C}$, and char residue at $650{ }^{\circ} \mathrm{C}$ more than $60 \%$. Conclusions: These resol resins have different gel times (8-55) min, and viscosities (435-350) mpa.s. The curing temperature of these resin obtained from DSC curves was $(120,129,105$ and $127^{\circ} \mathrm{C}$ ), while the thermal behavior of the cured resins obtained from TGA curves showed that these cured resin have two decomposition temperatures and the rate of decomposition in the order of $\mathrm{RC}<\mathrm{RR}<$

1 Department of Chemistry, College of Science, University of Basrah, Basra-Iraq, fahadmaaroof@gmail.com

2 Department of Chemistry, College of Science, University of Basrah, Basrah, Iraq, alassdik@yahoo.com

3 Department of Chemistry College of Science, University of Basrah, Basra-Iraq, whidadhanoosh@yahoo.com 


\section{INTRODUCCTION}

Phenolic resins are the oldest synthetic polymers used commercially around the beginning of the 20th century. These thermoset resins have typically been cured at high temperatures $(130-170){ }^{\circ} \mathrm{C}$ and usually high pressures. Commonly, phenolic resins are used in a broad range of applications such as paints, adhesives and, composites $\stackrel{(1,2)}{\text {. }}$.

There are two types of phenolic resin; the resol type and novolac type depending on the method of synthesis and the catalysts used ${ }^{(3,4)}$. Phenolic resin provides intermolecular hydrogen bonding as a domain driving force to interact with hydroxyl, carbonyl, amide, ester and other hydrogen bonding functional groups ${ }^{(5,6)}$. Also, the characteristic of the phenolic resin is to be determined by its physical properties, thermal and electrical properties ${ }^{(7)}$. During the last century phenolic resin played an important role as engineering plastics, at the first commercialized synthesis resin, phenol formaldehyde (PF) resin became indispensable because of it is excellent mechanical properties, thermal stability and chemical resistance ${ }^{(8,9)}$. Formaldehyde usually used as an aqueous solution between 35 and $40 \mathrm{wt}^{\mathrm{T}} \%$, is essential for the preparation of PF resin $\frac{(10,11)}{}$.

DSC and TGA have been used extensively to characterize the curing process and thermal stability of some phenolic resin. This present study was designed to synthesize, characterize and study of some properties of the phenolic resin. In order to achieve this objective, DSC was chosen to follow the thermal behavior and the cure chemistry while TGA used to evaluate the thermal stability of cured phenolic resin prepared in this study.

\section{MATERIALS AND METHOD}

Phenolic compounds (Resorcinol, Hydroquinone, Catechol, Phloroglucinol) and formalin solution $35 \%$ were purchased from fluka Co. other analytical chemicals such as sodium hydroxide pellets, ethanol, methanol, hydroxylamine hydrochloride, and hydrochloric acid (98\%) were obtained from Merck Co.

\section{CHN elemental analysis:}

The percent of carbon and hydrogen in the cured phenolic resins were measured using (Vario EL cube elemental analyzer).

\section{Viscosity Measurements:}

The viscosity of the phenolic resins (resols) prepared in this study was measured using Brookfield rotary Viscometer Type Alpha series code VI00002 with the spindle at $25 \pm 2{ }^{\circ} \mathrm{C}$. An average value of three replicate measurements was reported.

\section{Fourier Transform Infrared (FT-IR) Spectrosco- py Test:}

The FTIR spectra of cured phenolic resins were performed in Shimadzu, FTIR-8400S. Each spectrum was recorded in a frequency range of $400-4000$ cm-1 using potassium bromide $(\mathrm{KBr})$ disc. The $\mathrm{KBr}$ was previously oven-dried at $300{ }^{\circ} \mathrm{C}$ to reduce the interference of water.

\section{Differential Scanning Calorimetry (DSC) Test:}

DSC measurement was conducted on Shimadzu DSC-60. Dynamic scans were conducted in a temperature range of $25-350{ }^{\circ} \mathrm{C}$, at a constant heating rate of $10{ }^{\circ} \mathrm{C} / \mathrm{min}$, under a nitrogen atmosphere at a flux rate of $20 \mathrm{~mL} / \mathrm{min}$. About $10-15 \mathrm{mg}$ of uncured resin was used in an aluminum crucible.

Thermogravimetric Analysis (TGA):

TGA measurement was evaluated on TGAQ50V20.13Build39. The dynamic scan was 
measured in a temperature range $25-700{ }^{\circ} \mathrm{C}$, at constant heating rate of $50{ }^{\circ} \mathrm{C} / \mathrm{min}$, under a nitrogen atmosphere at a flow rate of $30 \mathrm{ml} / \mathrm{min}$.

\section{Free Formaldehyde Content:}

The free formaldehyde content (FFC) of the prepared the resin is determined by the hydroxylamine hydrochloride method. Accurately weighted about 0.003-0.005 $\mathrm{g}$ of the resin sample was transferred into $250 \mathrm{~mL}$ beaker and dissolved in $50 \mathrm{~mL}$ of meth$\mathrm{yl}$ alcohol. Simultaneously, the $\mathrm{pH}$ value of the solution was adjusted to 3.5 by adding $1 \mathrm{~N}$ hydrochloric acid solution. $25 \mathrm{~mL}$ of $10 \%$ Hydroxylamine hydrochloride solution was added and stirred for $10 \mathrm{~min}$. Finally, the mixture solution was titrated with $0.1 \mathrm{~N}$ sodium hydroxide solution. Free formaldehyde content was calculated by:

$$
\% \mathrm{FFC}=\frac{3 \mathrm{C}\left(\mathrm{V}_{1}-\mathrm{V}_{0}\right)}{\mathrm{m}}
$$

Where " $\mathrm{V}_{1}, \mathrm{~V}_{0}$ " are volumes of sodium hydroxide solution required in the titration for sample and blank respectively. "C" is the exact normality of sodium hydroxide solution; " $\mathrm{m}$ " is the weight of the sample in grams.

\section{Resin Solid Content:}

The percent of resin solid content (S), was calculated by the following equation:

$$
\% \mathrm{~S}=\frac{\mathrm{S}_{1}}{\mathrm{~S}_{0}} \times 100
$$

Where $\mathrm{S}_{0}$ and $\mathrm{S}_{1}$ are the weight of the resin before and after dried $\left(3 \mathrm{hrs}\right.$. at $\left.105^{\circ} \mathrm{C}\right)$ respectively.

\section{Synthesis:}

Synthesis of resol resins ${ }^{(12)}$ (general procedure): Resol prepolymer resins (RR, RH, RP, and RC) were synthesized with F/P molar ratio 1.5/1 in the presence of sodium hydroxide solution as a catalyst, in $250 \mathrm{ml} \mathrm{RB}$ flask fitted with a reflux condenser, mechanical stirrer, and digital thermometer. The resin was prepared by mixing the required amounts of phenolic compounds (used in this study) with formaldehyde solution $35 \%$. In the presence of $10 \%$ sodium hydroxide solution, the reaction mixture was stirred and heat at $90{ }^{\circ} \mathrm{C}$ for $1-1.5 \mathrm{hrs}$ until the mixture became viscose, then the mixture cooled to ambient temperature and neutralized by $10 \%$ phosphoric acid solution. The product was isolated from an aqueous solution, and dried under vacuum oven to get brown viscose material samples from each prepolymer isolated to DSC study.

\section{Curing of resol resin:}

The curing of the prepared resol resins was made by heating the resins first at $70{ }^{\circ} \mathrm{C}$ for $5 \mathrm{hrs}$ followed at $120^{\circ} \mathrm{C}$ for $3 \mathrm{hrs}$ and finally, post cure at $150{ }^{\circ} \mathrm{C}$ for $3 \mathrm{hrs}$ in order to complete cure chemistry. A sample from each resin was taken for TGA study ${ }^{(13)}$.

\section{RESULTS}

\section{Reaction mechanism:}

Typically, the resol is obtained at an F/P molar ratio more than one (excessive formaldehyde) with basic catalyst (eq. 1). Sodium hydroxide is the most often used catalyst, even though other base catalysts. The first step in resols polycondensation is the formation of phenolate ion and then electrophilic attack of carbonyl compound on the para- and ortho-position of a phenolate anion as shown in (eq. 2 and 3$) \stackrel{(13)}{\text {. }}$ 

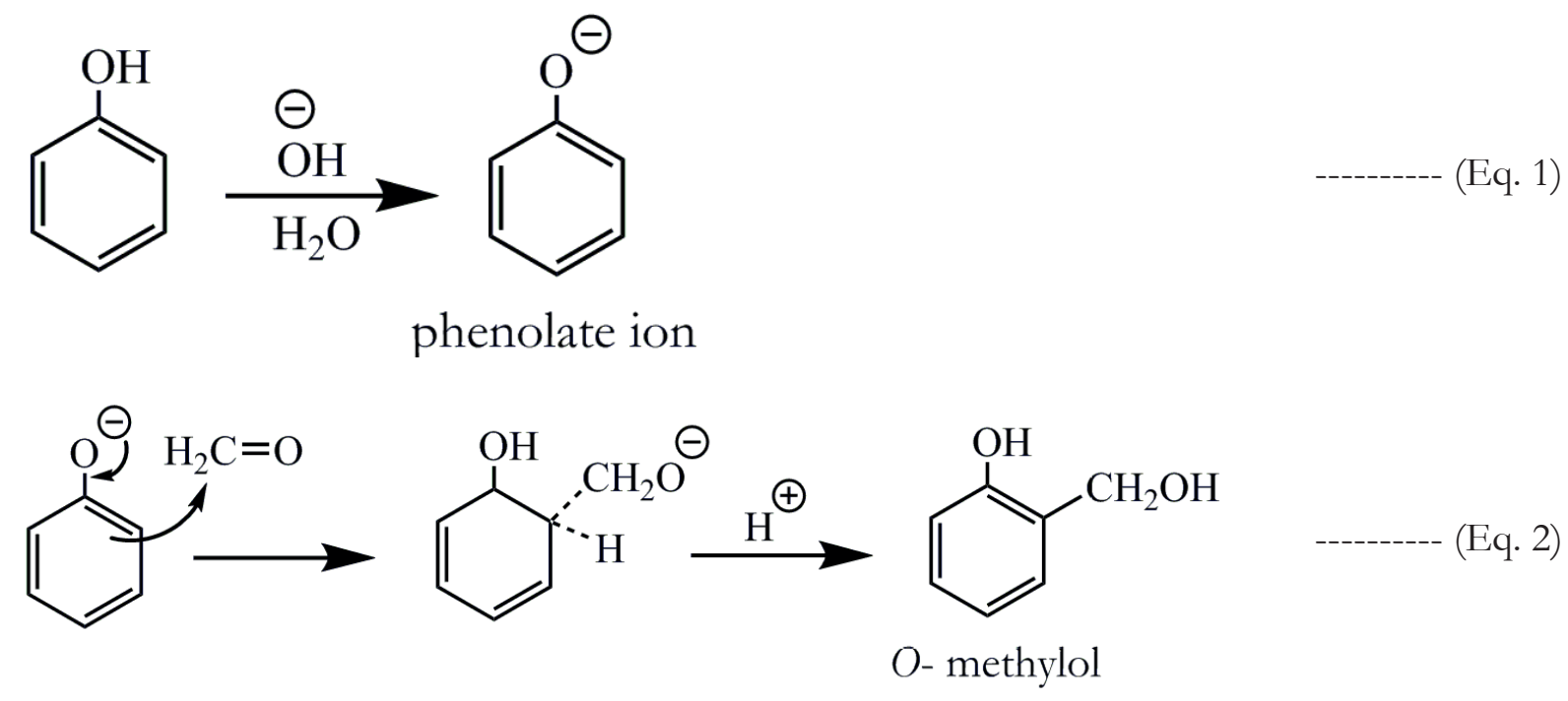

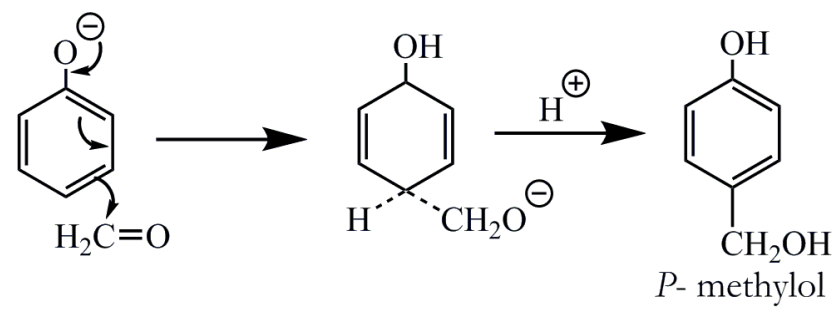

Sometime methylol groups can react to form dimethylene ether bridges under reactions with the generation of water according to (eq. 4) or methylol group reacts with the benzene ring to form methylene linkage<smiles>Oc1cccc(COCc2cccc(O)c2)c1</smiles>

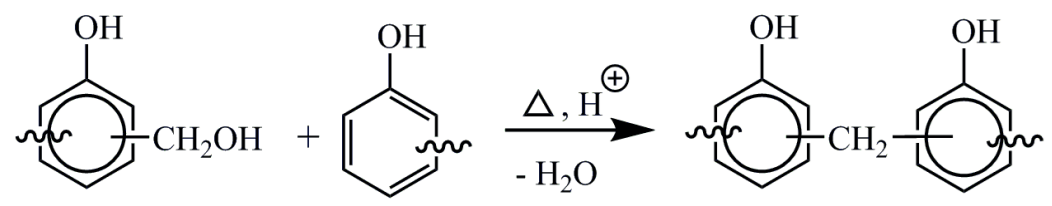

Then, the ether linkage (Eq. 4) converts after more heat under curing to methylene bridge with the generation of formaldehyde, as shown in (eq. 6).<smiles>O=C(OCc1ccccc1)c1ccc(OCc2cccc(O)c2)cc1</smiles>

Here the reactivity of phenolic resin differs slightly due to the position of the hydroxyl group so the result of gel time and dry solid content is shown in Table 1. From the results, the gel time of resol resins prepared from resorcinol was less than other phenolic compounds. Also, the dry solid content of the resol resin of resorcinol was
$69 \%$ which, is more than other phenolic resins due to more reactivity and more methylol groups present in their structures. The expected structure of the methylol resin prepared in this study are shown in Table 2, which indicated by CHN elemental analysis (Table 3 ). 
Table 1. Some physical properties of resol resins.

\begin{tabular}{ccccc}
\hline $\begin{array}{c}\text { Prepolymer } \\
\text { No. }\end{array}$ & $\begin{array}{c}\text { Free } \\
\text { Formaldehyde } \\
\text { Content } \%\end{array}$ & $\begin{array}{c}\text { Gel time (min) } \\
\text { Loss of fluidity } \\
\text { at } \mathbf{1 0 0}{ }^{\circ} \mathbf{C}\end{array}$ & $\begin{array}{c}\text { Viscosity } \\
\text { (mpa.s) } \\
\text { at } \mathbf{2 5} \mathbf{\circ}^{\circ} \mathbf{C} \pm 2\end{array}$ & $\begin{array}{c}\text { Dry solid content } \\
\mathbf{( \% )} \\
\text { at 105 }{ }^{\circ} \mathbf{C} 3 \text { hrs. }\end{array}$ \\
\hline RR & 0.12 & 8 & 435 & 66.51 \\
RH & 0.15 & 22 & 333 & 41.28 \\
RP & 0.11 & 55 & 412 & 59.81 \\
RC & 0.17 & 21 & 387 & 49.32 \\
\hline
\end{tabular}

Table 2. The expected structure of Resol Resins prepared in this study.<smiles>CCOCc1cc(COCC)c(O)cc1O</smiles>

RR<smiles>CCOCc1c(O)c(COCC)c(O)c(CC(C)(C)C)c1O</smiles>

RP<smiles>CCCCC(C)(C)COc1cc(O)c(COCC)cc1O</smiles>

$\mathrm{RH}$<smiles>CCOCc1cc(O)c(O)cc1COCC</smiles>

$\mathrm{RC}$

Table 3. CHN analysis.

\begin{tabular}{clll}
\hline \multirow{2}{*}{ Resin } & & \multicolumn{2}{c}{ Percent \% } \\
& & C & H \\
\hline \multirow{2}{*}{ RR } & theoretical & 56.467 & 5.923 \\
& experimental & 58.600 & 4.900 \\
\multirow{2}{*}{ RH } & theoretical & 56.467 & 5.923 \\
& experimental & 55.200 & 5.300 \\
\multirow{2}{*}{ RC } & theoretical & 56.467 & 5.923 \\
& experimental & 58.800 & 5.500 \\
\multirow{2}{*}{ RP } & theoretical & 50.001 & 5.594 \\
& experimental & 50.300 & 4.800 \\
\hline
\end{tabular}


FTIR-analysis:

The FTIR spectra of prepared phenolic resin are shown in Table 4, while the spectra are shown in figures (1-4).

Table 4. Some characteristic band in $\mathrm{cm}^{-1}$ of the prepared phenolic resin.

\begin{tabular}{ccccccc}
\hline Resol resin No. & -OH group & $\begin{array}{c}-\mathrm{CH} 2- \\
\text { Aliphatic }\end{array}$ & $\begin{array}{c}-\mathrm{C}=\mathrm{C}- \\
\text { Aromatic }\end{array}$ & $\begin{array}{c}-\mathrm{CH} 2- \\
\text { bending }\end{array}$ & C-O bond & $\begin{array}{c}\text { C-O-C } \\
\text { bond }\end{array}$ \\
\hline \multirow{2}{*}{ RR } & 3448.84 & 2854.74 & 1608.76 & 147752 & 129235 & 1093.57 \\
& & 2926.11 & & & & \\
RH & 3417.98 & 2955.04 & 1647.26 & 1435.09 & 1249.91 & 1116.82 \\
RP & 3423.76 & 2969.46 & 1622.19 & 1462.09 & 1249.91 & 1116.82 \\
RC & 3462.70 & 2951.19 & 1608.69 & 1442.80 & 1180.47 & 993.73 \\
\hline
\end{tabular}

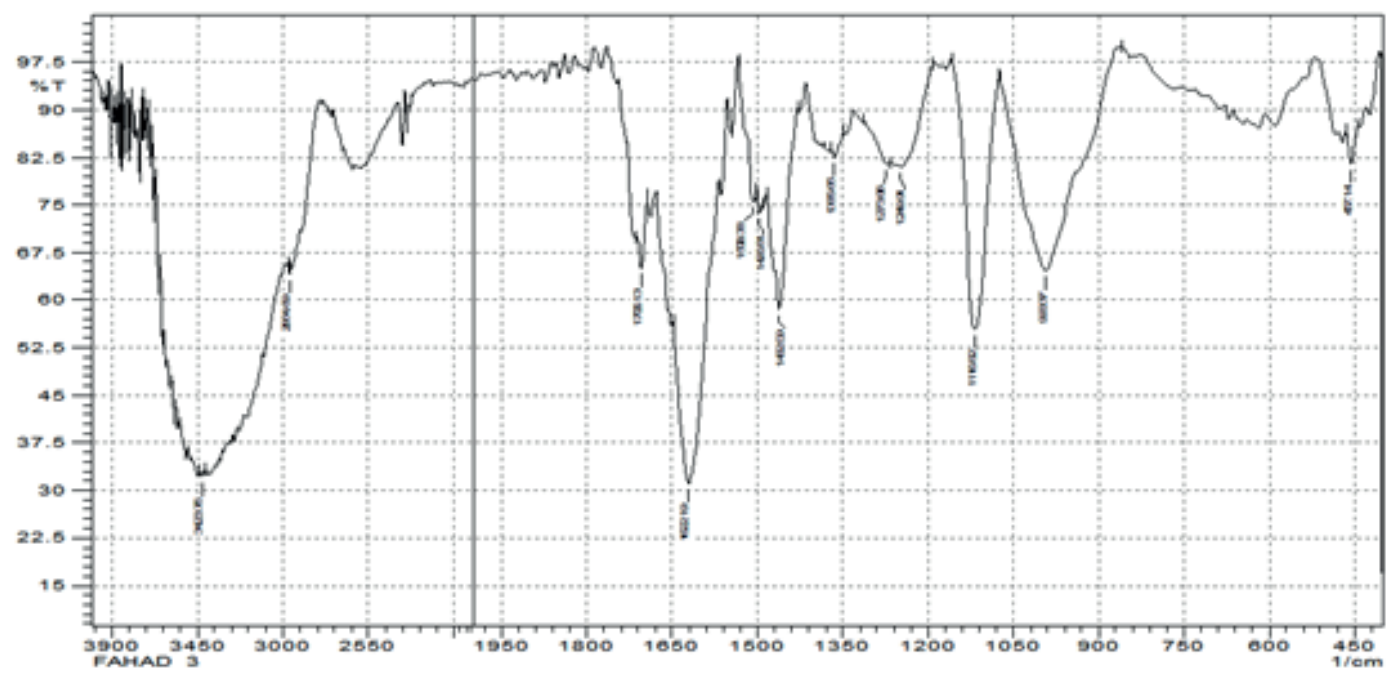

Figure 1. The FTIR spectrum of the RR phenolic resin

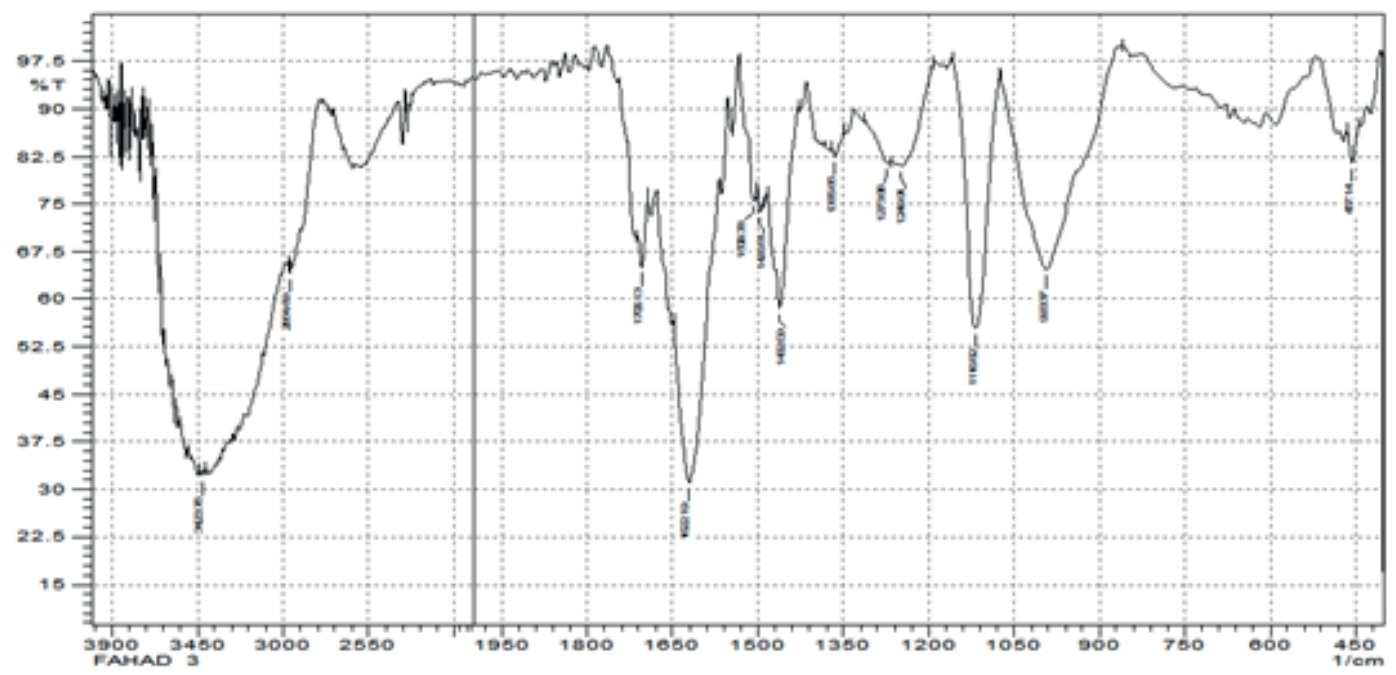

Figure 2. The FTIR spectrum of the RH phenolic resin 


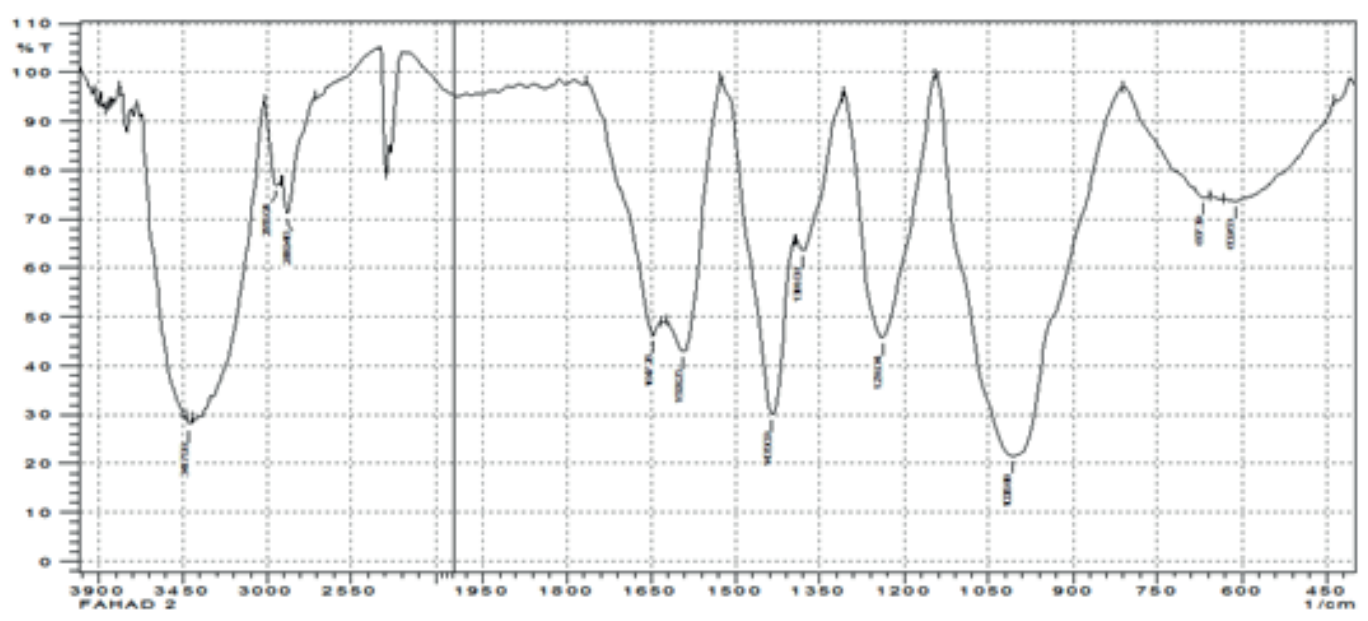

Figure 3. The FTIR spectrum of the RP phenolic resin

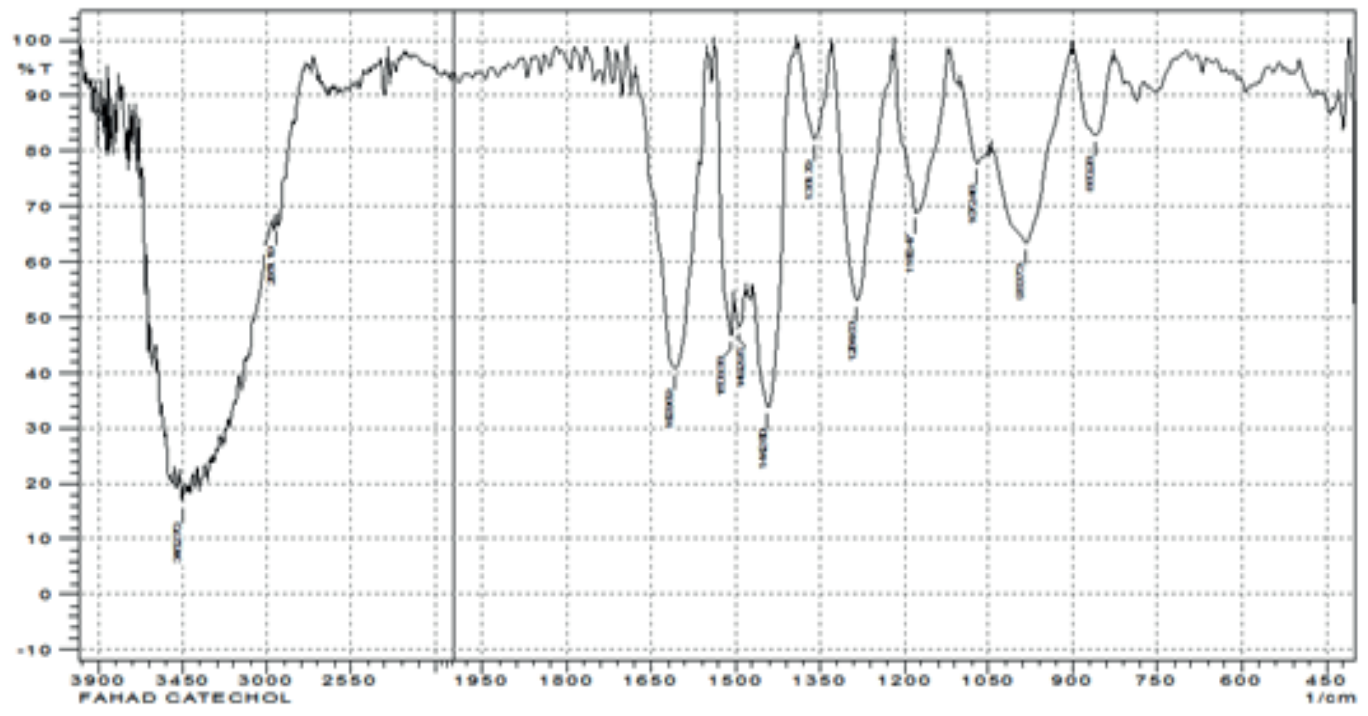

Figure 4. The FTIR spectrum of the RC phenolic resin

\section{Thermal study:}

\section{TGA study:}

The thermal stability of polymers is defined as the resistance of polymers towards thermal or thermochemical degradation $\frac{(15,16)}{}$. The thermal stability of any material can be expressed either as a function of temperature or as temperature, time limit. The thermal behavior of polymers can be investigated by several techniques such as thermal gravimetric analysis (TGA), differential thermal analysis (DTA), dynamic mechanical analysis (DMA) and differential scanning calorimetry (DSC). The thermal degradation of phenolic resin has been widely reported $(17,18)$. Mainly, it focused on the chemistry of the main vola- tile products. Different mechanisms for the degradation process and for a different range of temperature were proposed for some type of phenolic resin $\stackrel{(19)}{\text {. }}$ So the thermal degradation of the prepared phenolic resin occurs by scission of polymer chains forming some volatile compounds and residue products, and the percentage of char residue depends on the presence of aromatic structure in their polymer chains. Figures (5-8) show the TGA/DTG thermograms of four cured resol resins prepared in this study, while the thermal parameters obtained from these thermograms are listed in the Table (5 and 6) respectively. 
Table 5. Some thermal parameter of cured resol resin obtained from TGA thermograms.

\begin{tabular}{ccccc}
\hline Polymer no. & Decomposition temp. ${ }^{\circ} \mathbf{C}$ & $\begin{array}{c}\text { Temp. of } \mathbf{5 0} \% \\
\text { weight loss }\end{array}$ & $\begin{array}{c}\text { Char residue } \\
\text { at } \mathbf{6 5 0} \mathbf{~}^{\circ} \mathbf{C}\end{array}$ & $\begin{array}{c}\text { Rate of de } \\
\text { composition } \% \mathbf{m i n}\end{array}$ \\
\hline RR & $408,549,578$ & $>700$ & 72 & 0.023 \\
RH & $155,313,517,574$ & $>700$ & 63 & 0.028 \\
RP & 374,530 & $>700$ & 68 & 0.024 \\
RC & $186,346,384$ & $>700$ & 81 & 0.015 \\
\hline
\end{tabular}

Table 6. Weight loss percentage of the cured resol resins at different temperatures obtained from TGA thermograms.

\begin{tabular}{cccccc}
\hline Polymer no. & $\begin{array}{c}\text { Weight loss } \% \\
\text { at } \mathbf{1 0 0}{ }^{\circ} \mathbf{C}\end{array}$ & $\begin{array}{c}\text { Weight loss \% } \\
\text { at } \mathbf{2 0 0}{ }^{\circ} \mathbf{C}\end{array}$ & $\begin{array}{c}\text { Weight loss } \% \\
\text { at } \mathbf{3 0 0}{ }^{\circ} \mathbf{C}\end{array}$ & $\begin{array}{c}\text { Weight loss \% } \\
\text { at } \mathbf{4 0 0}{ }^{\circ} \mathbf{C}\end{array}$ & $\begin{array}{c}\text { Weight loss \% } \\
\text { at } \mathbf{5 0 0}{ }^{\circ} \mathbf{C}\end{array}$ \\
\hline RR & 1.58 & 3.16 & 3.95 & 7.36 & 14.74 \\
RH & 1.32 & 2.37 & 4.47 & 12.50 & 20.00 \\
RP & 2.11 & 4.21 & 6.32 & 14.74 & 21.58 \\
RC & 0.33 & 1.70 & 3.50 & 8.00 & 16.30 \\
\hline
\end{tabular}

Sample: Fahad1 Size: $28.0300 \mathrm{mg}$ Method: Ramp
TGA
File: C:...ISajadiDesktoplChemistry\Fahad1.002 Operator: Prof.Dr.salah /Dr. Khansa

Run Date: 01-Jan-2010 01:28

Instrument: TGA Q50 V20.13 Build 39

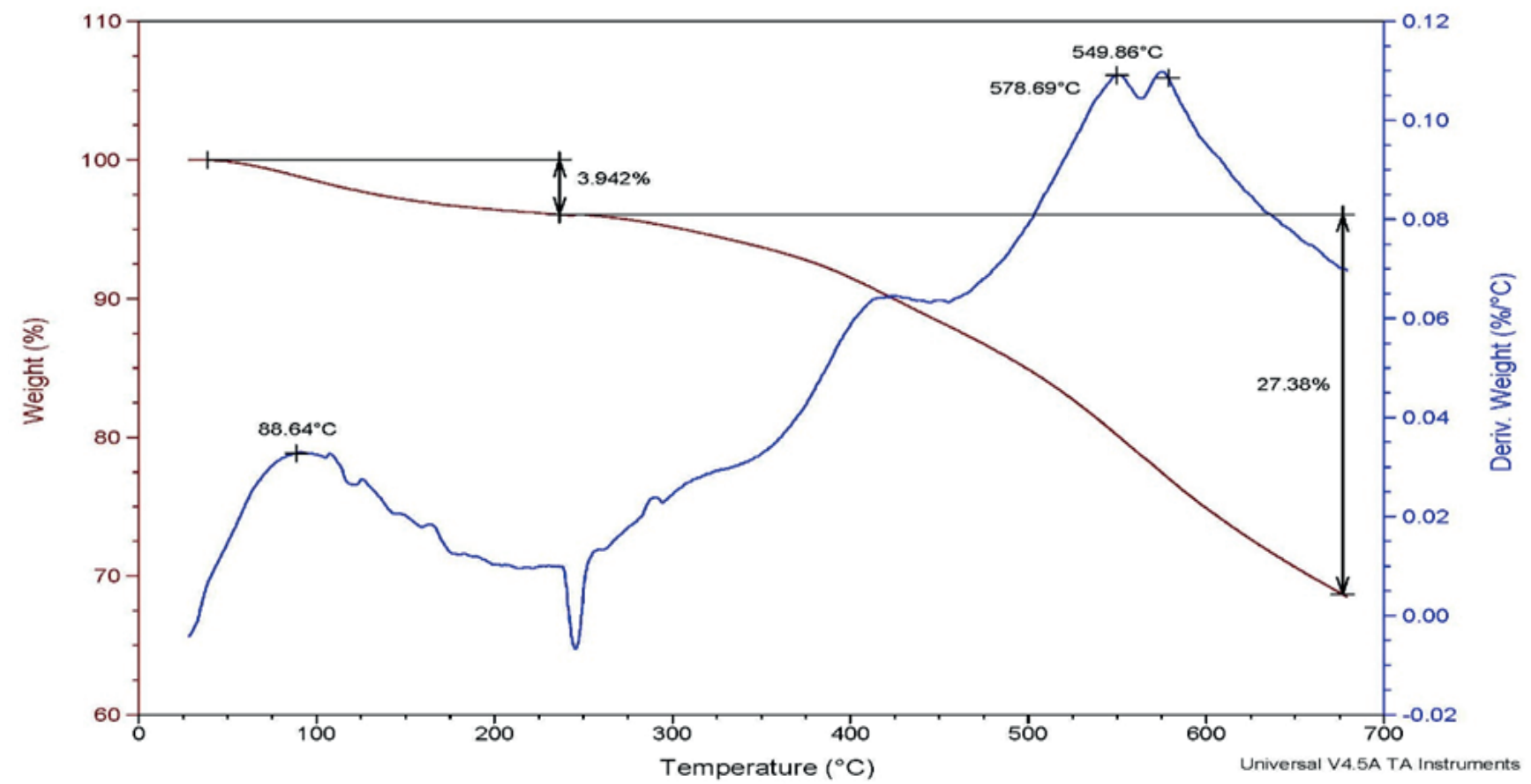

Figure 5. TGA/DTG thermogram of cured (RR) resin. 


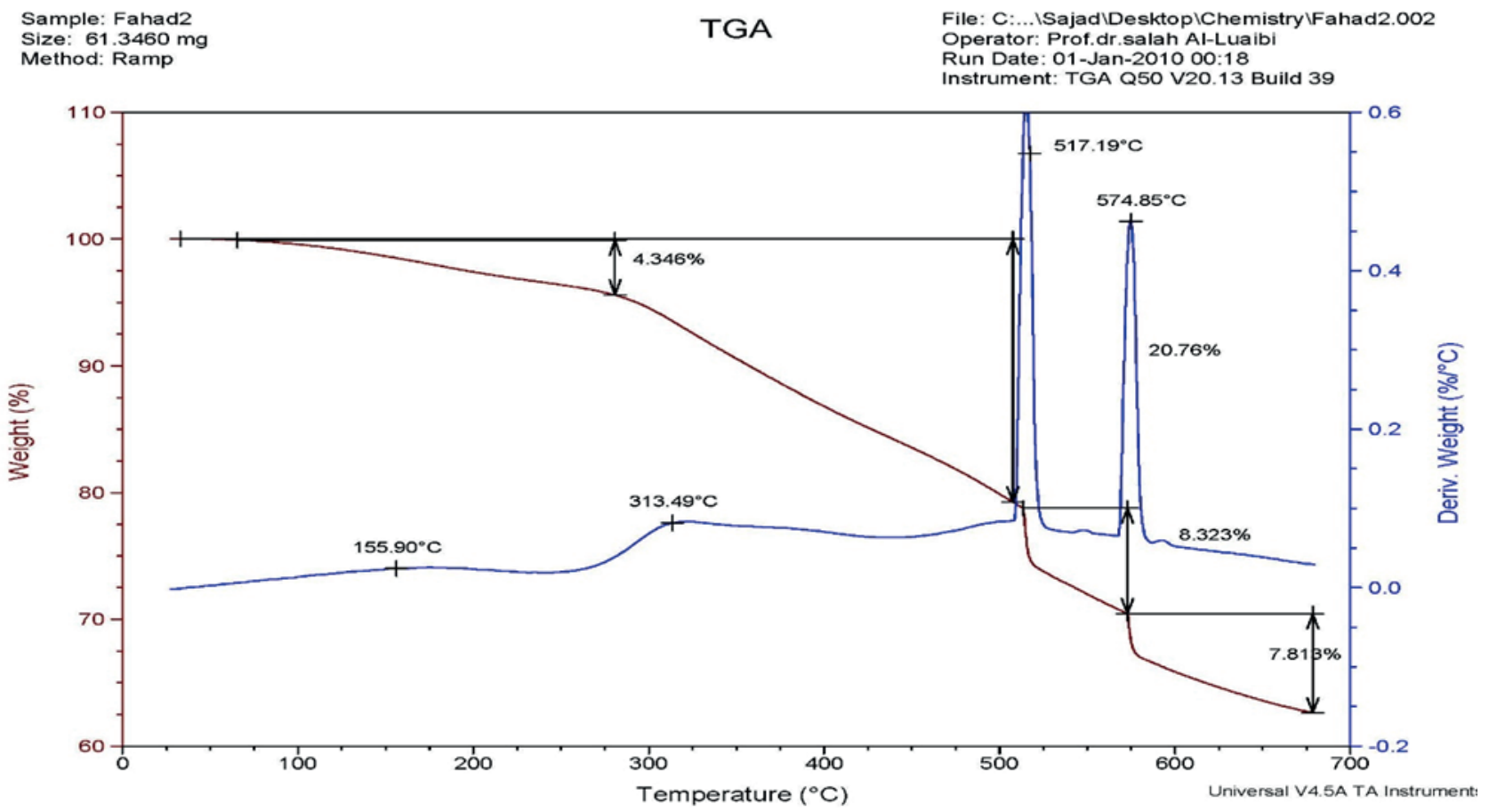

Figure 6. TGA/DTG thermogram of cured $(\mathrm{RH})$ resin.

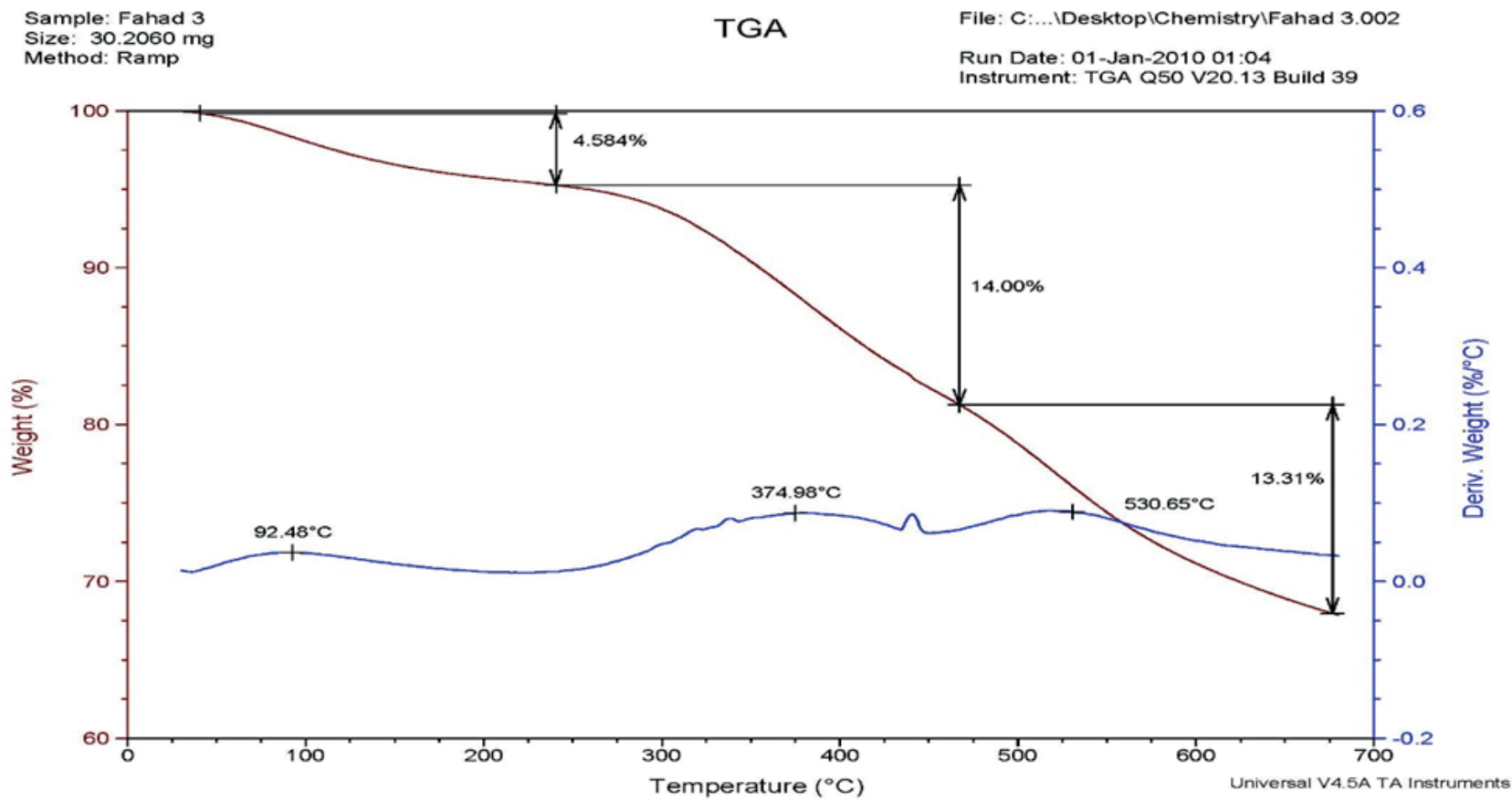

Figure 7. TGA/DTG thermogram of cured (RP) resin 


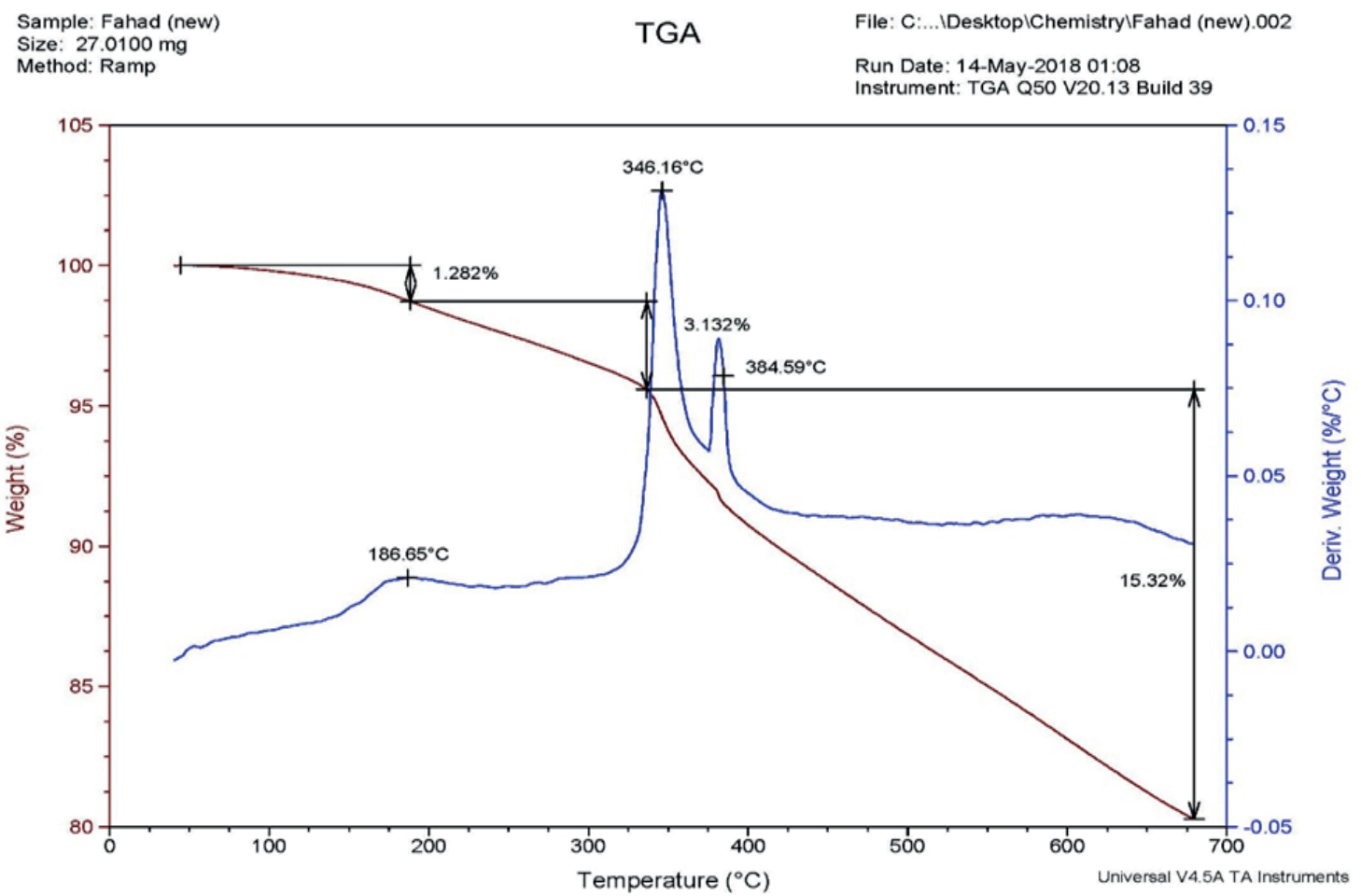

Figure 8. TGA/DTG thermogram of cured (RC) resin.

\section{DSC study:}

DSC has been used extensively in the study of physical transformations and chemical reactions and chemical reactions of materials $\frac{(20,21)}{2}$. The basic assumption for application of DSC to the cure of thermoset polymers is that the measured heat flow of the reaction as a function of the temperature. Several parameters can be detected from DSC measurements like curing energy of polymerization, the temperature of cure, enthalpy relaxation and glass transition temperature of cured polymers ${ }^{(22)}$.
All DSC measurements were made on a Shimadzu DSC-60 with a single heating rate of $5{ }^{\circ} \mathrm{C} / \mathrm{min}$ and a scanning temperature range from 25 to 350 ${ }^{\circ} \mathrm{C}$. Analysis of the results of these dynamic scans is listed in the Table (7), while the thermograms curves of DSC for the prepared resol resins are shown in Figures (9-12).

Table 7. Thermal parameter of resol resins obtained from DSC thermograms

\begin{tabular}{cccc}
\hline Resins no. & Onset temperatures ${ }^{\circ} \mathbf{C}$ & Cure temperature ${ }^{\circ} \mathbf{C}$ & Curing energy $\mathbf{J} / \mathbf{g}$ \\
\hline RR & 101 & 120 & 340.71 \\
& 124 & 129 & 23.39 \\
$\mathrm{RH}$ & 157 & 182 & 158.31 \\
& 114 & 105 & 16.31 \\
$\mathrm{RP}$ & 137 & 141 & 3.77 \\
& 121 & 127 & 1.83 \\
$\mathrm{RC}$ & 140 & 155 & 17.02 \\
& & & 35.64 \\
\end{tabular}




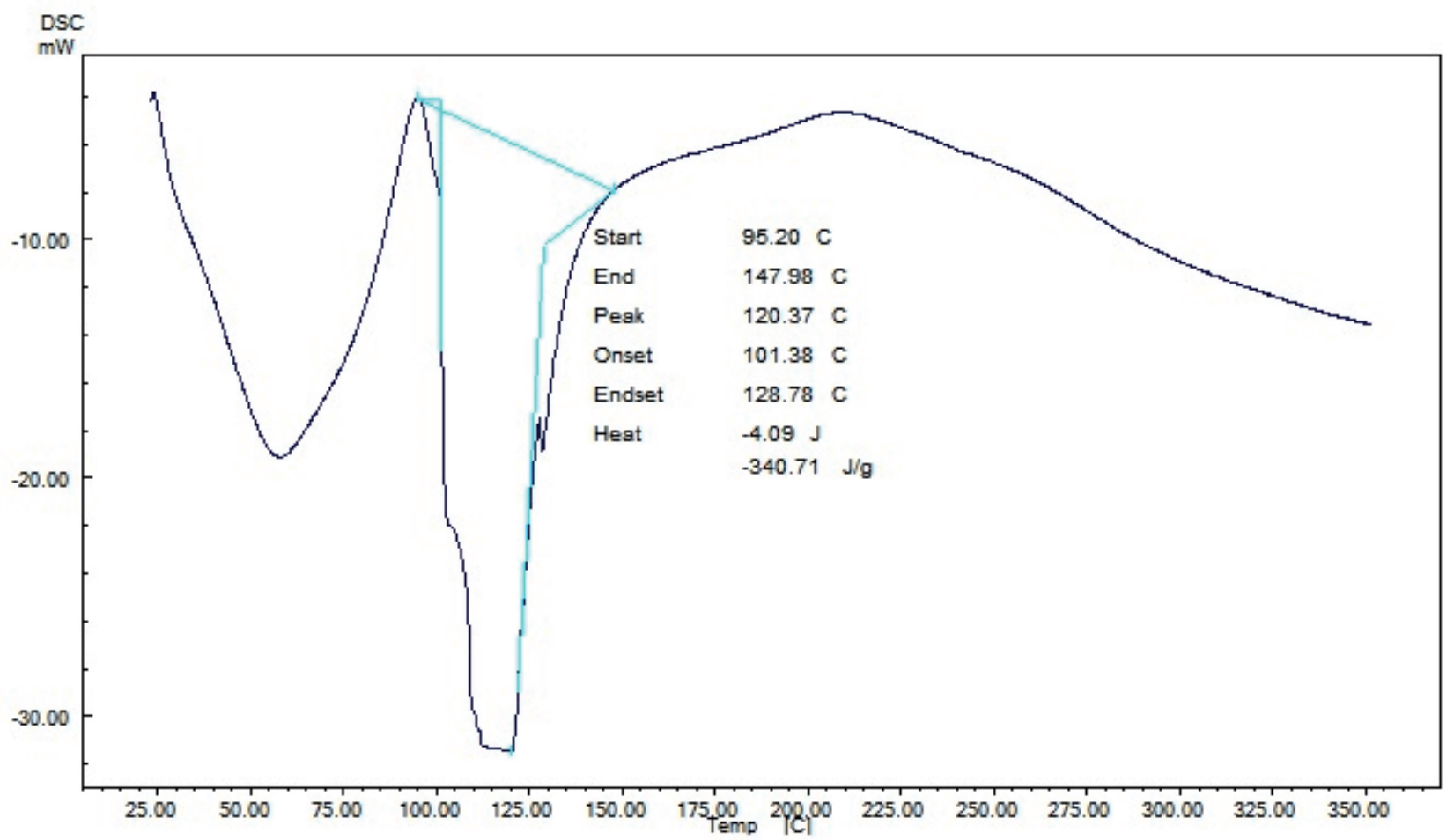

Figure 9. DSC thermogram of uncured phenolic resin (RR)

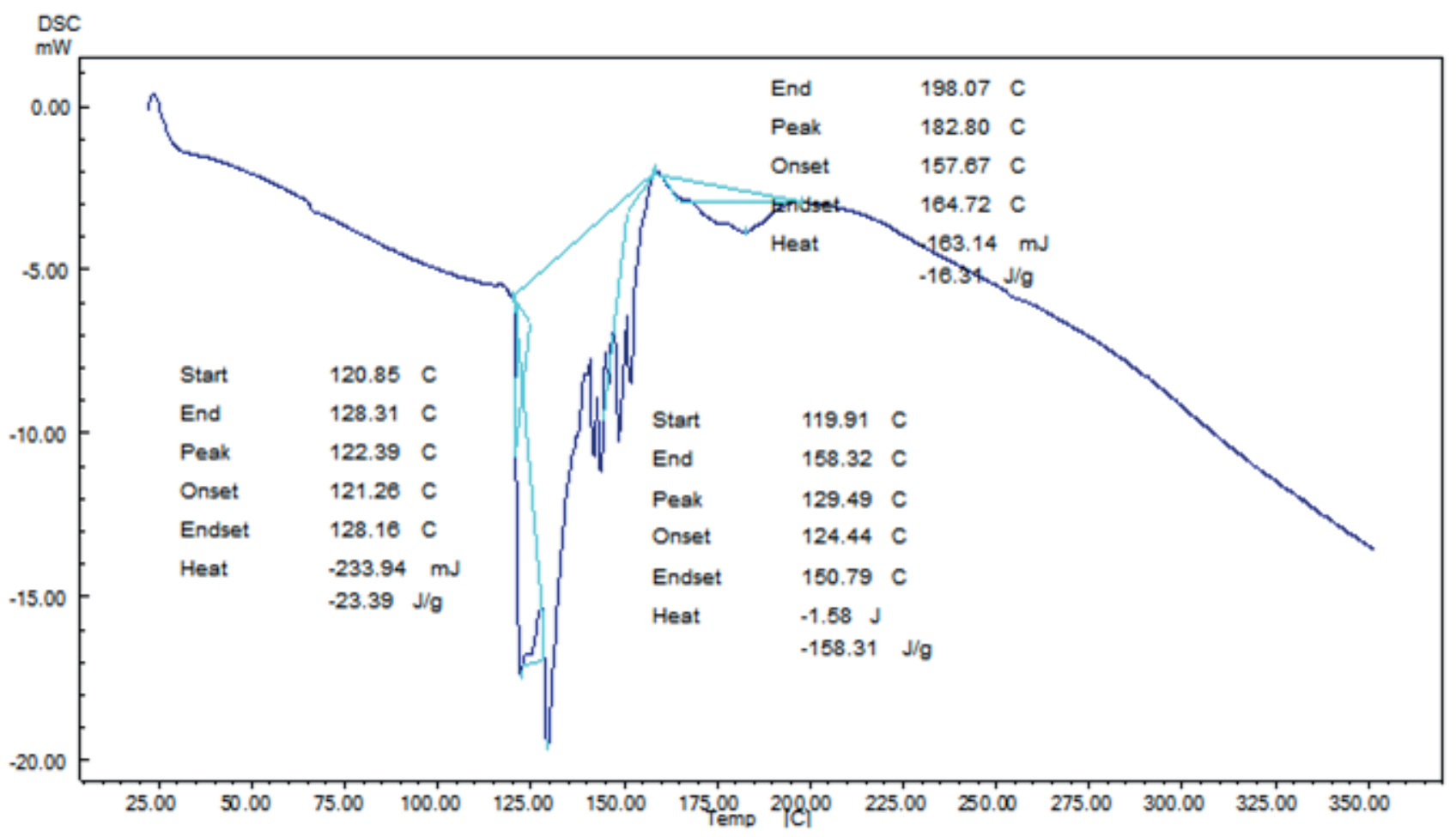

Figure 10. DSC thermogram of uncured phenolic resin $(\mathrm{RH})$. 


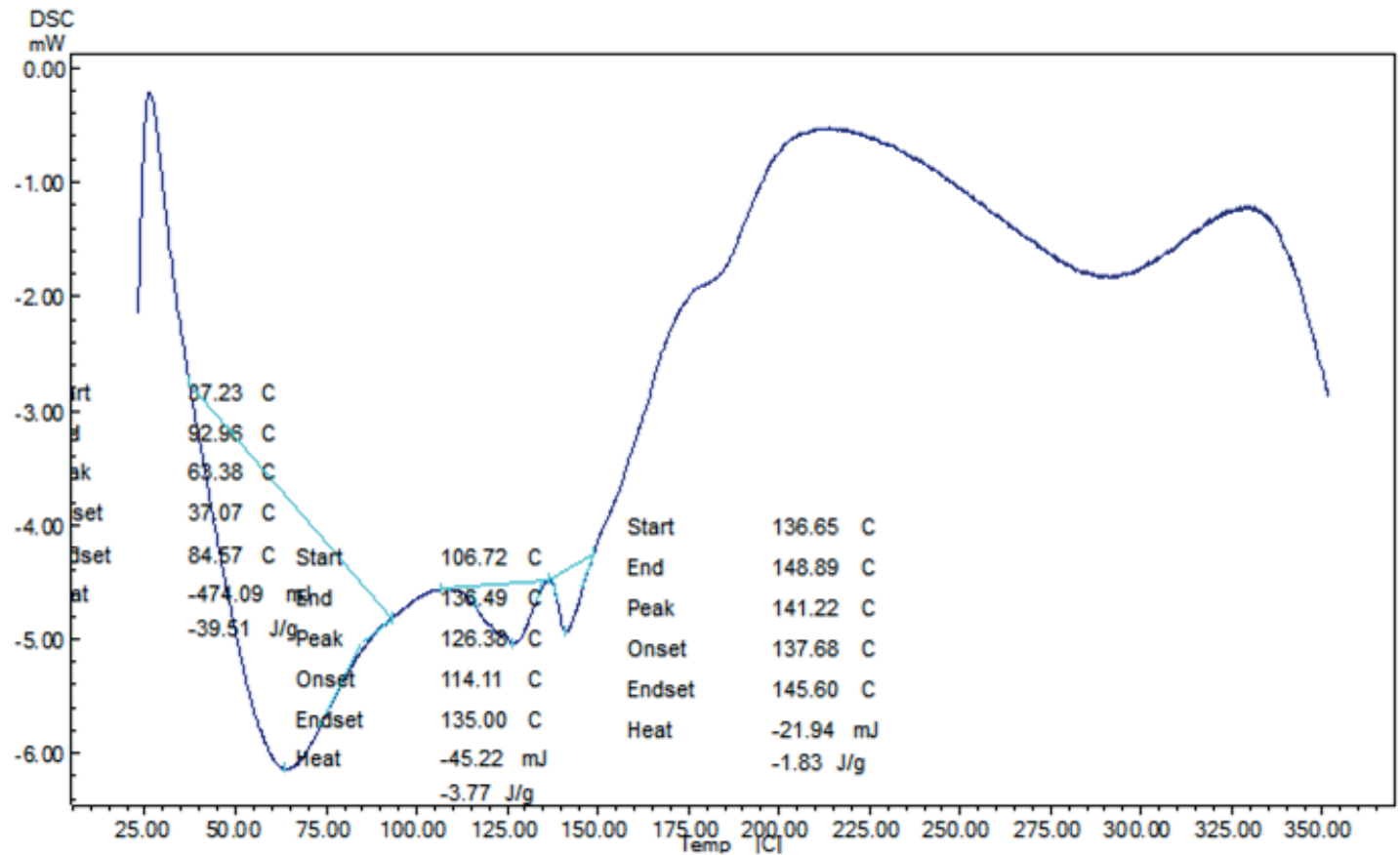

Figure 11. DSC thermogram of uncured phenolic resin (RP).

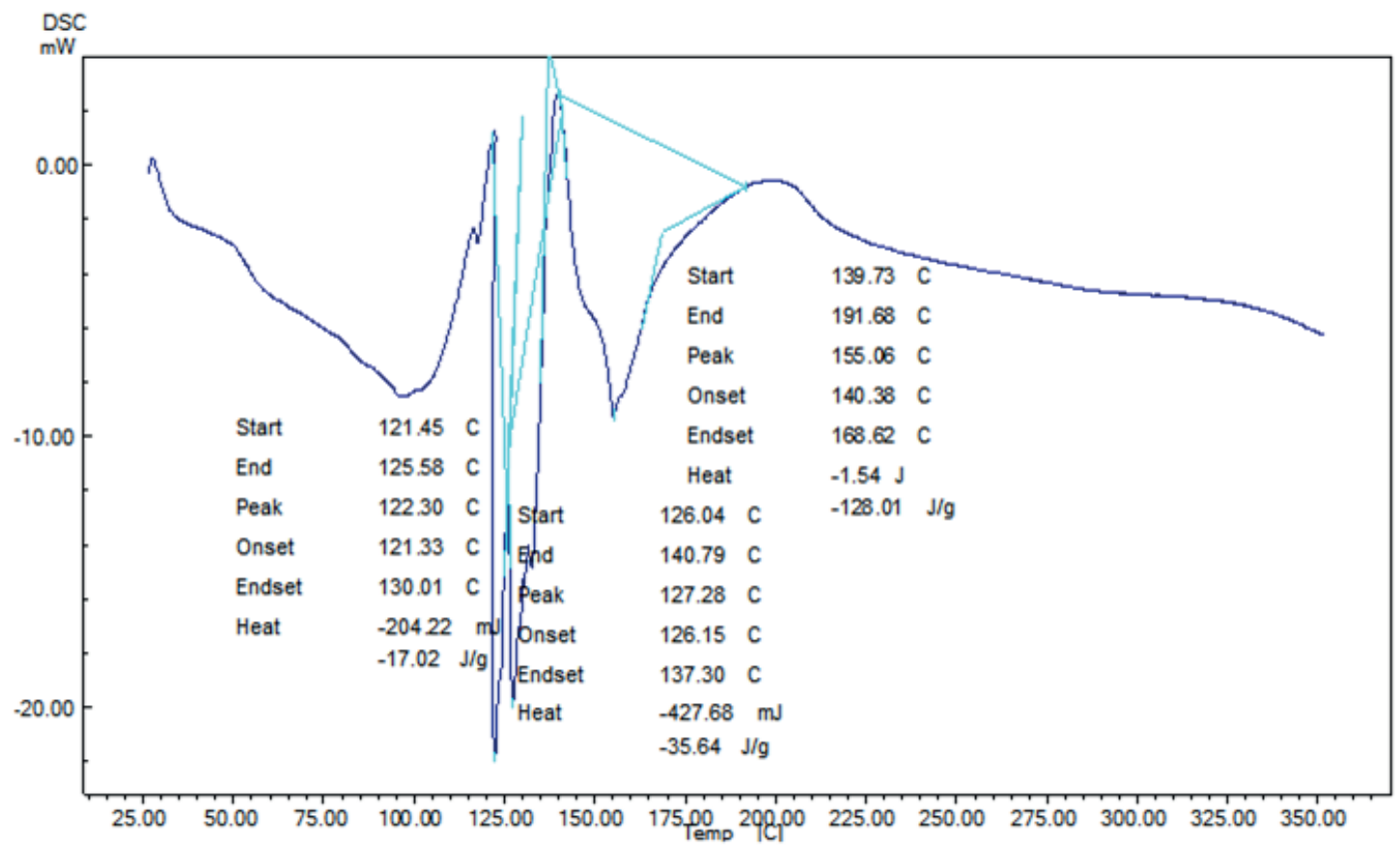

Figure 12. DSC thermogram of uncured phenolic resin (RC).

\section{DISCUSSION}

\section{FTIR analysis:}

From the result, the significant peaks was due to some stretch and bending vibration of functional groups present in their structure like hydroxyl group, aliphatic $\mathrm{CH}_{2}$-group, $\mathrm{C}=\mathrm{C}$ aromatic double bond and $\mathrm{C}-\mathrm{O}$ and $\mathrm{C}-\mathrm{O}-\mathrm{C}$ stretching vibrations $\stackrel{(23,24)}{ }$. The position of the peaks of those groups somewhat different for the prepared resol resins in this study due to the differences in their chemical environments. 


\section{TGA analysis:}

From the result in Tables (5 and 6), it is possible to conclude that these resins have several decomposition temperatures more than $155^{\circ} \mathrm{C}$, while the char residue was more than $60 \%$ due to the formation polyaromatic hydrocarbons in the network structures and the trends of these resins are $(\mathrm{RC}>\mathrm{RR}>$ RT $>$ RH). On the other hand, the rate of decomposition of these resins is in the order $(\mathrm{RC}<\mathrm{RR}<$ $\mathrm{RP}<\mathrm{RH})$. The general structures formed through the thermal degradation of the prepared phenolic resin in this study are as indicated in some literature (25,26). Most phenolic resins start by the rupture of methylene bridges (present through the polymerization of phenolic compounds with formaldehyde), followed by breaks in phenolic functions and finally the formation of the polyaromatic networks (which indicate the formation of char residue after thermal treatments). The expected mechanism of decomposition is shown in Scheme 1.<smiles>CCc1c(O)c(C)cc(C)c1O</smiles><smiles>CCc1cc(I)c(O)c(CC)c1O</smiles><smiles>C1CC1</smiles>

Formation of phenolic compounds<smiles>CCc1cc(Cc2cc(CC)c(O)c(CC)c2O)c(O)c(CC)c1O</smiles>

$\mathrm{CO}, \mathrm{CO}_{2}, \mathrm{CH}_{4}, \mathrm{H}_{2}$

Formation of phenolic compounds

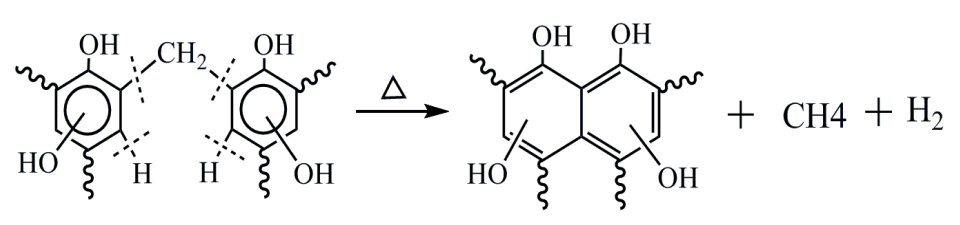

Formation of polyaromatic Hydrocarbones-PAH

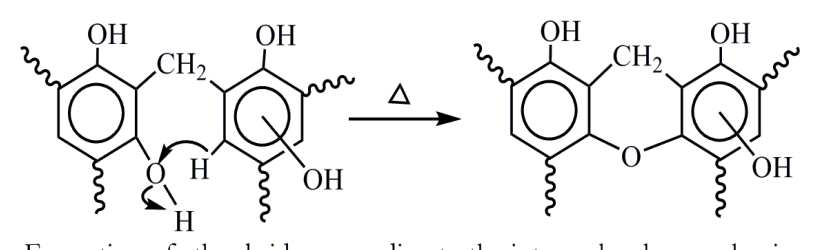

Formation of ether bridge according to the intramolecular mec hanism
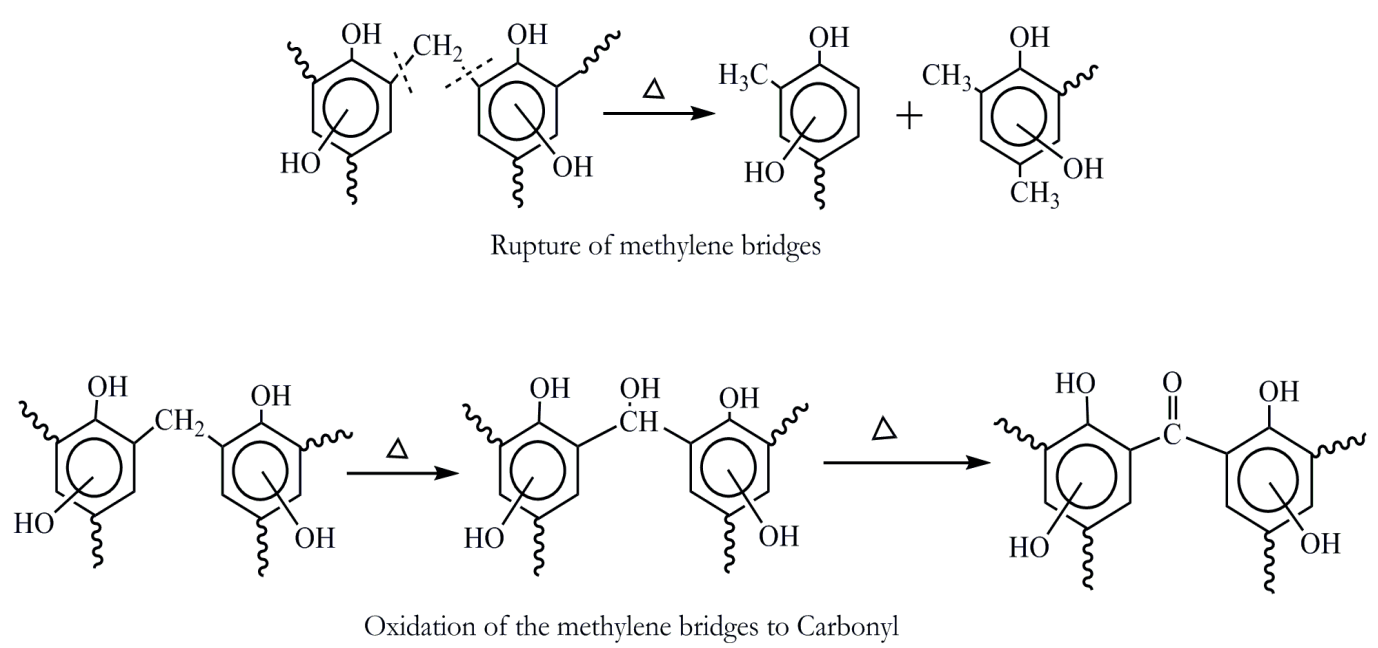

Scheme 1. The expected mechanism for the thermal degradation of 
The general structures of degradation of the prepared phenolic resins start by the rupture of methylene bridges (present through the polymerization of phenolic compounds), followed by breaks in phenolic functions and finally the formation of polyaromatic networks (which indicate the formation of char residue after thermal treatments).

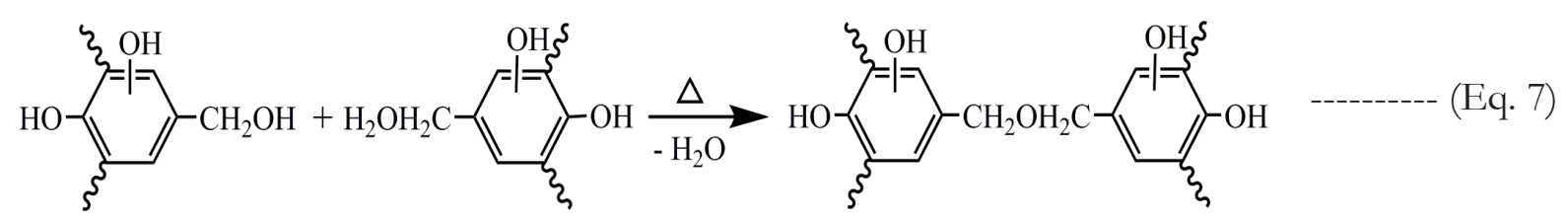
ing any catalyst. showing in eq. 7.
Another reaction takes place for the most phenolic resins (resols) ${ }^{277}$. During the evolution of formaldehyde under

\section{DSC analysis:}

All the resol resins exhibit an endothermic peak during the curing under heat condition without us-

From the result, the curing reaction of resol resins of the four phenolic compounds involved mainly two steps, first condensation reaction occurs between methylol groups of the adjusted polymer chains leading to the formation of the ether linkage as

heating to the formation of methylene bridges as showing in eq. 8.
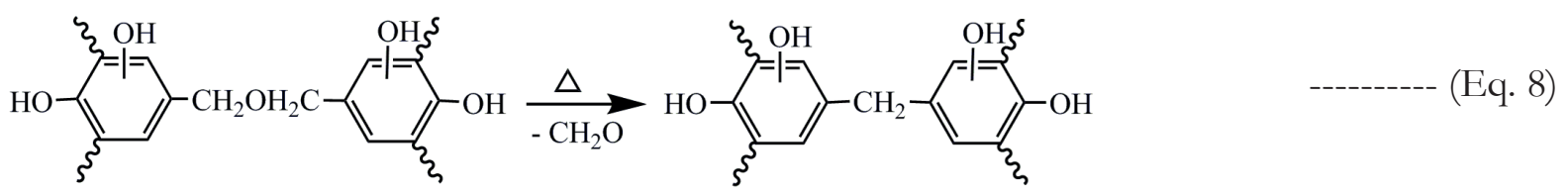

This reaction mainly occurs at a temperature of more than $120^{\circ} \mathrm{C}$. In this study, different curing energy will be obtained this lead to differences in the reactivity of phenolic compounds and also due to how much methylol groups present in their structures.

\section{CONCLUSIONS}

Phenolic resins (resol) were prepared through polycondensation of phenolic compounds with formaldehyde using sodium hydroxide as catalyst. These resol resins have different gel times (8-55) min, and viscosities (350-435) mpa.s. The curing temperature of these resin obtained from DSC curves was (120, 129,105 and $127^{\circ} \mathrm{C}$ ), while the thermal behavior of the cured resins obtained from TGA curves showed that these cured resin have several decomposition temperatures, higher char content and the rate of decomposition in the order of $\mathrm{RC}<\mathrm{RR}<\mathrm{RP}<\mathrm{RH}$.

\section{REFERENCES}

1. Wang M, Leitch M, Xu CC. Synthesis of phenol-formaldehyde resol resins using organosolv pine lignins. European Polymer Journal. 2009;45(12):3380-8.

https://doi.org/10.1016/j.eurpolymj.2009.10.003

2. Yuan Z, Zhang Y, Xu CC. Synthesis and thermomechanical property study of Novolac phenol-hydroxymethyl furfural (PHMF) resin. RSC Advances. 2014;4(60):31829-35.

https://doi.org/10.1039/C4RA04458D

3. Pilato L. Resin chemistry. Phenolic Resins: A Century of Progress: Springer; 2010. p. 41-91. https://doi.org/10.1007/978-3-642-04714-5 4

4. Yan N, Zhang B, Zhao Y, Farnood RR, Shi J. Application of Biobased Phenol Formaldehyde Novolac Resin Derived from Beetle Infested Lodgepole Pine Barks for Thermal Molding of Wood Composites. Industrial \& Engineering Chemistry Research. 2017;56(22):6369-77. https://doi.org/10.1021/acs.iecr.7b00353 
5. Chen-Chi M, Sung S-C, Wang F-Y, Chiang LY, Wang LY, Chiang C-L. Thermal, mechanical, and morphological Properties of Novolac-Type Phenolic Resin Blended with Fullerenol Polyurethane and Linear Polyurethane. Composites: Part B. 2001;36:2436-43.

\section{https://doi.org/10.1002/polb.1215}

6. Wang FY, Ma CCM, Wu HD. Hydrogen bonding in polyamide toughened novolac type phenolic resin. Journal of applied polymer science. 1999; 74(9):2283-9.

https://doi.org/10.1002/(SICI)10974628(19991128)74:9<2283::AID - APP18>3.0.CO;2-X

7. Allin SB. Polymer Science and Technology, 2nd Edition (Joel R. Fried). Journal of Chemical Education. 2004;81(6):809.

https://doi.org/10.1021/ed081p809

8. Choi MH, Chung IJ. Mechanical and thermal properties of phenolic resin-layered silicate nanocomposites synthesized by melt intercalation. Journal of Applied Polymer Science. 2003;90(9):2316-21. https://doi.org/10.1002/app.12763

9. Shukla SK, Srivastava K, Srivastava D. Studies on the thermal, mechanical and chemical resistance properties of natural resource derived polymers. Materials Research. 2015;18(6):1217-23.

https://doi.org/10.1590/1516-1439.007715

10. Lee YK, Kim DJ, Kim HJ, Hwang TS, Rafailovich $\mathrm{M}$, Sokolov J. Activation energy and curing behavior of resol-and novolac-type phenolic resins by differential scanning calorimetry and thermogravimetric analysis. Journal of applied polymer science. 2003;89(10):2589-96.

https://doi.org/10.1002/app.12340

11. Park B-D, Riedl B, Hsu EW, Shields J. Differential scanning calorimetry of phenol-formaldehyde resins cure-accelerated by carbonates. Polymer. 1999;40(7):1689-99.

https://doi.org/10.1016/S0032-3861(98)00400-5

12. Heath R. Aldehyde Polymers: Phenolics and Aminoplastics. Brydson's Plastics Materials (Eighth Edition): Elsevier; 2017. p. 705-42.

https://doi.org/10.1016/B978-0-323-35824$\underline{8.00025-6}$

13. Fink JK. Reactive polymers: Fundamentals and applications: A concise guide to industrial polymers: William Andrew; 2017.
14. Grenier-Loustalot M-F, Raffin G, Salino B, Païsé O. Phenolic resins Part 6. Identifications of volatile organic molecules during thermal treatment of neat resols and resol filled with glass fibers. Polymer. 2000;41(19):7123-32.

https://doi.org/10.1016/S0032-3861(00)00045-8

15. Schawe JE, Ziegelmeier S. Determination of the thermal short time stability of polymers by fast scanning calorimetry. Thermochimica Acta. 2016;623:80-5.

https://doi.org/10.1016/j.tca.2015.11.020

16. Samoilenko V, Atyasova E, Blaznov A, Zimin D, Tatarintseva O, Khodakova N. A study of heat resistance of polymer/epoxy composites. Polzunovskiy Vestnik. 2015(4):131-5.

17. Chen ZQ, Chen YF, Liu HB, editors. Study on thermal degradation of phenolic resin. Applied Mechanics and Materials; 2013: Trans Tech Publ. https://doi.org/10.4028/www.scientific.net/ AMM.422.24

18. Chen Y, Fan D, Qin T, Chu F. Thermal degradation and stability of accelerated-curing phenol-formaldehyde resin. BioResources. 2014;9(3):4063-75.

https://doi.org/10.15376/biores.9.3.4063-4075

19. Chen Y, Chen Z, Xiao S, Liu H. A novel thermal degradation mechanism of phenol-formaldehyde type resins. Thermochimica Acta. 2008;476(12):39-43.

https://doi.org/10.1016/j.tca.2008.04.013

20.Schindler A, Doedt M, Gezgin Ş, Menzel J, Schmölzer S. Identification of polymers by means of DSC, TG, STA and computer-assisted database search. Journal of Thermal Analysis and Calorimetry. 2017;129(2):833-42.

https://doi.org/10.1007/s10973-017-6208-5

21. Gaisford S, Kett V, Haines P. Principles of thermal analysis and calorimetry: Royal society of chemistry; 2016.

22. He G, Riedl B. Curing kinetics of phenol formaldehyde resin and wood-resin interactions in the presence of wood substrates. Wood Science and Technology. 2004;38(1):69-81.

https://doi.org/10.1007/s00226-003-0221-5

23. Theophanides T. Infrared spectroscopy-materials science, engineering and technology 2012.

https://doi.org/10.5772/47117 
24. Siesler HW, Ozaki Y, Kawata S, Heise HM. Near-infrared spectroscopy: principles, instruments, applications: John Wiley \& Sons; 2008.

25. Gao J, Liu Y, Yang L. Thermal stability of boron-containing phenol formaldehyde resin. Polymer degradation and stability. 1999;63(1):19-22. https://doi.org/10.1016/S0141-3910(98)00056-1

26. Fyfe CA, McKinnon MS, Rudin A, Tchir WJ. Investigation of the mechanism of the thermal decomposition of cured phenolic resins by high-resolution carbon-13 CP/MAS solid-state NMR spectroscopy. Macromolecules. 1983;16(7):12169. https://doi.org/10.1021/ma00241a033

27.Zhao Y, Yan N, Feng MW. Thermal degradation characteristics of phenol-formaldehyde resins derived from beetle infested pine barks. Thermochimica Acta. 2013;555:46-52.

https://doi.org/10.1016/j.tca.2012.12.002 